\author{
Н. О. Свтушенко \\ Академія економічних наук України, м. Київ, Украӥна
}

\title{
ПОДАТКОВІ РИЗИКИ ТА СИСТЕМА КЕРУВАННЯ НИМИ
}

Статтю присвячено дослідженню сучасного стану системи оподаткування в період їі реформування та подальшим розробкам в галузі фундаментальних основ оподаткування.

Метою написання статті с поглиблене вивчення природи, сутності ризиків у сфері оподаткування, розгляд змісту системи керування ризиками та обгрунтування концептуальних основ ефективності керування податковими ризиками шляхом запровадження системного підходу в умовах великої частки тіньової економіки. Дослідження проведено із застосуванням методів дедукції та індукції, системного підходу, аналізу й синтезу на основі законодавчої бази України, даних Держаної фіскальної служби України, даних Державної служби статистики України, праць вітчизняних і закордонних економістів, матеріалів авторських досліджень.

Досліджено сутність і місце податкових ризиків у системі керування ними. Доведено, що податковий, а також економічний ризики зазвичай занадто переоцінюють, оскільки щодо витрат заходи 3 підвищення результатів діяльності людського капіталу дуже розпливчаті та сформовані у недосконалих інформаційних умовах.

3'ясовано необхідність системного підходу до керування податковими ризиками. Розглянуто основні елементи системи керування податковими ризиками. Доведено вплив людського капіталу та інформації на ефективність керування податковими ризиками.

Акцентовано увагу на доцільності вивчення податкових ризиків у системі керування i мінімізації протидії. Доведено, що така система може бути описана як сукупність деяких методів, процедур і заходів і надас можливість прогнозувати дефіцит податкових платежів та вживати заходи стосовно мінімізації порушень у податковій сфері.

Розглянуто основні елементи системи керування податковими ризиками. Дана система являє собою сукупність взаємопов'язаних і взаємозалежних елементів, таких як: 1) суть та оригінальні джерела ризику; 2) аналіз, оцінка й опис ризику; 3) методи мінімізації ризиків; 4) моніторинг заходів щодо запобігання і протидії ризику.

Доведено, що метод систематизації платників застосовують відповідно до стандартів для визначення податкових ризиків у системі їх керування. Такий підхід дозволить упровадити на практиці нову стратегію організації контрольно-ревізійної роботи та істотно скоротити витрати на здійснення планових перевірок.

Наголошено, що податкові ризики слід розглядати як наукову основу для розробки критерію ефективності побудови систем забезпечення національної податкової безпеки. Як i будь-які ризики, податкові ризики повинні бути не тільки визначені , але й зведені до мінімуму. Для цього доцільно застосувати систему керування податковими ризиками як сукупність деяких методів, процедур і заходів. Використання людського капіталу та інформаційного забезпечення дозволить досягти необхідного рівня ефективності.

Застосування системного підходу в теоії i практиці оподаткування допоможе передбачати негативні наслідки впливу зовнішнього середовища, сприятиме ефективності моніторингу ризиків i їx практичному керуванню. Податкова служба може підвищити обсяг податкових надходжень до бюджету за рахунок зменшення податкових злочинів (ухилення від сплати податків). Це, в свою чергу, призведе виходу економіки 3 тіні.

Науковою новизною дослідження с поглиблення та визначення природи, сутності податкових ризиків, а також обгрунтування концептуальних основ ефективності їх керування через запровадження системного підходу.

Урахування системного підходу дозволить фіскальним службам ефективно керувати податковими ризиками.

Перспективним напрямком досліджень с перегляд нормативної документації Державної фіскальної служби на основі системного підходу та врахування податкового ризику як виміру результатів діяльності людського капіталу й недосконалого інформаційного забезпечення.

Ключові слова: податковий ризик; керування податковими ризиками; система керування податковими ризиками; податкова система; держава; платник податків.

(C) Євтушенко Н. O., 2016 


\section{Н. А. Евтушенко \\ Академия экономических наук Украины, г. Киев, Украина}

\section{НАЛОГОВЫЕ РИСКИ И СИСТЕМА УПРАВЛЕНИЯ НИМИ}

Статья посвящена исследованию современного состояния системы налогообложения в период реформирования и дальнейшим разработкам в области фундаментальных основ налогообложения.

Целью написания статьи является углубленное изучение природы, сущности рисков в сфере налогообложения, рассмотрения содержания системы управления рисками и обоснование концептуальных основ эффективности управления налоговыми рисками путем внедрения системного подхода в условиях большой доли теневой экономики. Исследование проведено с применением методов дедукции и индукции, системного подхода, анализа и синтеза на основе законодательной базы Украины, данных Государственной фискальной службы Украины, данных Государственной службы статистики Украины, работ отечественных и зарубежных экономистов, материалов авторских исследований.

Исследована сущность и место налоговых рисков в системе управления ними. Доказано, что налоговый, а также экономический риски, как правило, переоценивают, поскольку с точки зрения затрат меры по повышению результатов деятельности человеческого капитала очень расплывчатые и сформированы в несовершенных информационных условиях.

Выяснена необходимость системного подхода к управлению налоговыми рисками. Рассмотрены основные элементы системы управления налоговыми рисками. Доказано влияние человеческого капитала и информации на эффективность управления налоговыми рисками.

Акцентировано внимание на целесообразности изучения налоговых рисков в системе управления и минимизации противодействия. Доказано, что такая система может быть описана как совокупность некоторых методов, процедур и мероприятий и позволяет делать прогнозы дефицита налоговых платежей и принимать меры по минимизации нарушений в налоговой сфере.

Рассмотрены основные элементы системы управления налоговыми рисками. Данная система представляет собой совокупность взаимосвязанных и взаимозависимых элементов, таких как: 1) суть и оригинальные источники риска; 2) анализ, оценка и описание риска; 3) методы минимизации рисков; 4) мониторинг мероприятий по предотвращению и противодействию риску.

Доказано, что метод систематизации налогоплательщиков применяется в соответствии с определенными стандартами для определения налоговых рисков в системе их управления. Такой подход позволит внедрить на практике новую стратегию организации контрольноревизионной работы и существенно сократить расходы осуществления плановых проверок.

Акцентировано внимание, что налоговые риски следует рассматривать в качестве научной основы для разработки критерия основы для построения систем обеспечения национальной налоговой безопасности. Как и любые риски, налоговые риски должны быть не только определенны, но и сведены к минимуму. В этом может помочь применение системы управления налоговыми рисками как совокупности некоторых методов, процедур и мероприятий. Использование человеческого капитала и информационного обеспечения позволит достичь обязательного уровня эффективности.

Применение системного подхода В теори и практике налогообложения поможет предвидеть негативные последствия воздействия внешней среды, способствовать эффективности мониторинга рисков и их практическому управлению. Налоговая служба может повысить уровень налоговых поступлений в бюджет за счет уменьшения налоговых преступлений (уклонение от уплаты налогов). Это приведет к выходу экономики из тени.

Научной новизной исследования является углубление и определения природы, сущности налоговых рисков, а также обоснование концептуальных основ эффективности их управления путем внедрения системного подхода. Учет системного подхода позволит эффективно управлять налоговыми рисками в деятельности фискальных служб.

Перспективным направлением исследований является пересмотр нормативной документации Государственной фискальной службы на основе системного подхода и учета налогового риска как измерения результатов деятельности человеческого капитала и несовершенного информационного обеспечения.

Ключевые слова: налоговый риск; управление налоговыми рисками; система управления налоговыми рисками; налоговая система; государство; налогоплательщик 


\author{
N. O. Evtushenko \\ Academy of Economic Science of Ukraine, Kyiv, Ukraine
}

\title{
TAXATION RISKS AND THE SYSTEM OF THEIR MANAGEMENT
}

The paper is devoted to the study of the current state of taxation system in the period of its reform and to further designs in the field of fundamental bases of taxation.

The purpose of writing this article is an in-depth study of the nature, the essence of risks in the sphere of taxation, consideration of the content of the system of the risk management and substantiation of conceptual bases of the efficiency of the taxation risk management by introducing a systematic approach under conditions of a large share of the shadow economy. The study was conducted with the use of the methods of deduction and induction, system approach, analysis and synthesis on the basis of the legislative framework of Ukraine, data by the state fiscal service of Ukraine, data by the state statistics service of Ukraine, papers by domestic and foreign economists, materials of the authors' research.

The nature and position of taxation risks in the system of their management were studied. It is proven that the taxation, as well as economic, risks are usually too overestimated, because as far as the cost is concerned, the measures to improve the performance results of human capital are very vague and formed under imperfect information conditions.

The need for a systematic approach to managing taxation risks was identified. The main elements of the management system of taxation risks were considered. The influence of human capital and information on the efficiency of taxation risks management was proven.

Special attention is paid to the feasibility study of taxation risks in the system of their management and to minimization of countermeasures. It is proven that such a system can be described as a set of certain methods, procedures and measures that makes it possible to forecast the deficit of tax payments and to take measures in regard to minimizing abuses in the taxation field.

The main elements of the taxation risks management system were considered. This system is a set of interconnected and interrelated elements such as: 1) the essence and the original sources of risk; 2) analysis, evaluation and description of the risk; 3) methods of minimizing risks; 4) monitoring of measures of prevention and counteraction of risk.

It is proven that the method of systematization of the taxpayers is applied according to the standards for determining the taxation risks in the system of their management. This approach will allow implementing into practice a new strategy of organization of the control and revision work with significant reduction in the cost of implementation of planned inspections.

It is stressed that the taxation risks should be considered as a scientific basis for the design of the criterion of the efficiency of creating systems of national taxation security. Like any risk, taxation risks must not be identified only, but kept to a minimum. To do this, it is advisable to apply a taxation risks management system as a set of certain methods, procedures and activities. The use of human capital and information software will provide for reaching the necessary level of efficiency.

The application of a systematic approach in the theory and practice of taxation will help to anticipate the negative consequences of the impact of the external environment; will contribute to the efficient monitoring of the risks and their practical management. The fiscal service may increase the amount of tax revenue to the budget by reducing tax abuses (tax evasion). This, in turn, will promote the exit of the economy out of the shadow.

Scientific novelty of the research is in the deepening and determining the nature and the essence of taxation risks, as well as the substantiation of conceptual bases of the efficiency of their management through the implementation of a systematic approach.

Adopting a systemic approach will allow fiscal services to efficiently manage taxation risks.

A promising area of research is to review regulating documentation of the state fiscal service on the basis of a systematic approach and consideration of taxation risk as a measurement of results of human capital performance and imperfect information provision.

Keywords: taxation risk, taxation risks management, taxation risks management system, taxation system, state, taxpayer.

Вступ. У процесі внормування української податкової системи відповідно до європейських стандартів оподаткування виникає необхідність дослідити податкові ризики та систему керування ними. Податкові ризики в системі оподаткування України є вагомими. Порушення виконання фіскальної та регулюючої функцій податків і принципів економічної й соціальної справедливості негативно впливає на стан національної економіки. Питання, пов'язані з податковими ризиками й 
системою керування ними, як ніколи потребують фундаментальних досліджень. Такі дослідження сприятимуть узагальненню економіко-правового розуміння діяльності зобов'язаних суб'єктів податкових відносин в аспекті виконання ними функцій і принципів оподаткування, підвищенню рівня податкової дисципліни. Це потребує від держави, яка реформуватиме податкову систему, розробити напрями іiі практичної розбудови й обрати модель керування 3 урахуванням фактора невизначеності. Тому розгляд питань стосовно формування системи керування податковими ризиками є актуальний.

Значну увагу в розробці концептуальних основ державної політики приділено концепції ризиків. Питання теорії ризиків досліджували у своїх працях такі вчені, як В. В. Вітлінський, М. С. Клапків, С. С. Осадець, А. В. Скрипник, C. I. Наконечний та ін. Незважаючи на суттєві наукові доробки в галузі дослідження ризиків, сфера аналізу податкових ризиків поки що залишається малодослідженою. Серед робіт 3 питань теорії і практики оподаткування та податкових ризиків варто виділити праці відомих вітчизняних вчених: $\begin{array}{llll}\text { В. Л. Андрущенка, } & \text { В. П. Вишневського, I. О. Луніної, } & \text { О. М. Тимченко, }\end{array}$ О. Д. Вовчак, П. В. Мельника, В. М. Опаріна, В. А. Онищенка, А. М. Соколовської, О. М. Десятнюк та ін. Крім того, питання податкової безпеки та іiі структурних елементів досліджували такі вітчизняні науковці, як С. В. Каламбет, А. І. Крисоватий, Н. В. Новицька, Ц. Г. Огонь, С. В. Онишко. Однак на теоретичному рівні питання щодо можливостей формувати й застосовувати механізм системи керування податковими ризиками ще не досліджені.

Постановка завдання. Метою написання статті $\epsilon$ поглиблене вивчення природи, сутності ризиків у сфері оподаткування, розгляд змісту системи керування ризиками та обгрунтування концептуальних основ ефективності керування податковими ризиками через запровадження системного підходу в умовах великої частки тіньової економіки. Дослідження проведено із застосуванням методів дедукції та індукції, системного підходу, аналізу та синтезу на основі законодавчої бази України, даних Держаної фіскальної служби України, даних Державної служби статистики України, праці вітчизняних і закордонних економістів, матеріалів авторських досліджень.

Результати. Ризик є складовим елементом будь-якої керувальної діяльності та залежить від множини факторів та дій контрагентів, вплив яких передбачити в усій повноті із необхідною точністю неможливо. За авторським визначенням, економічний ризик - це вартісний вимір результатів фінансово-господарської діяльності людського капіталу через невикористані можливості в умовах невизначеності подій i недосконалості інформаційного забезпечення [1, c. 5]. Одним із різновидів економічного ризику $\epsilon$ податковий ризик, який має всі характеристики загальноекономічних ризиків: конфліктність, всеохоплюваність, імовірність, невизначеність та альтернативність. Податковий ризик, як i економічний ризик, доцільно визначати як вартісний вимір результатів діяльності людського капіталу в умовах невизначеності та недосконалості інформаційного забезпечення. Основою невизначеності в системі керування податковими ризиками $\epsilon$ невизначеність і недостовірність інформації, під впливом яких виникають порушення у фінансових потоках. У певний період часу порушення в даних потоках перетворюються на ризиковані. Однак виявлення, розпізнавання й керування податковими ризиками є завданням працівників, які в постіндустріальній економіці отримали назву «людський капітал».

Згідно 3 наказом Державної податкової адміністрації України «Про затвердження методичних рекомендацій 3 моніторингу податкових ризиків», 
податковий ризик трактується як вірогідність порушення податкового законодавства, внаслідок чого можливі втрати бюджету [2]. Тобто ці порушення виникають між податківцем або уповноваженою особою Державної податкової служби та платником податків.

Податковий ризик 3 погляду держави в особі їі уповноважених органів - це ймовірність (загроза) недоотримати податки в бюджет через використання платниками податків методів мінімізації (оптимізації) оподаткування, можливих через ті чи інші недоліки в податковому законодавстві. Податковий ризик з погляду платника податків - це ймовірність (загроза) донарахувати йому податки (збори), пеню й штрафи в ході податкової перевірки через розбіжності, що виникли між даними платника податків і податківців, у трактуванні податкового законодавства, яка може спричинити зростання податкового тягаря для господарюючого суб'єкта [3].

Розгляд сутності податкових ризиків дає підстави врахувати той факт, що ризик включає не стільки наявність ризикової ситуації і іiі усвідомлення, стільки прийняття рішення на основі проведення аналізу та моніторингу ризику. Тому податкові ризики, як і будь-який ризик, потрібно не тільки передбачати, а й мінімізувати, тобто керувати ними. У таких умовах необхідно створити наукову концепції ризикології у сфері оподаткування, що стане важливим теоретичним підгрунтям розбудови вітчизняної податкової системи [4].

У процесі керування податковими ризиками доцільно використовувати системний підхід, який фокусує увагу не тільки на організації, але й на середовищі, що іiі оточує. Центральним для нього $є$ поняття «система». В економіці система являє собою складний механізм, для якого характерні причинно-наслідкові взаємодії. Деякі західноєвропейські економісти дотримуються думки, що керування ризиком - це дії, здатні забезпечувати стабільність відповідної діяльності шляхом включення можливих втратних випадків до процесу керування [5, с. 646-647].

Вищенаведені міркування, з урахуванням думки авторів роботи [12], дають підстави вважати, що систему керування податковими ризиками можна охарактеризувати як сукупність взаємопов'язаних і взаємозалежних елементів, до яких відносять:

- сутність ризику та джерела його виникнення;

- аналіз, оцінка й опис ризику (характеристика ризику);

- сукупність методів, прийомів і заходів, які дозволяють прогнозувати надходження податкових платежів і вжити заходів із мінімізації порушень у цій сфері;

- методи мінімізації ризику;

- моніторинг заходів запобігання й протидії ризикам.

У системі керування податковими ризиками його об'єктом є соціальні цінності, на які спрямовані конкретні посягання у сфері оподаткування, що призводять до ненадходження коштів до бюджету чи державних цільових фондів. До суб'єктів керування податковими ризиками можна віднести представників державних податкових органів, які за допомогою різних прийомів i способів керування цілеспрямовано впливають на податкові ризики.

Створення Державної податкової адміністрації в Україні потребувало використання зарубіжного досвіду. Щоб створити партнерські відносини та атмосферу повної довіри й поваги між податковою службою і платниками податків, за приклад обрано досвід діяльності Податкової та митної адміністрації 
Нідерландів,оскільки в цій державі, рівень добровільної сплати податків становить 97 \%. Основний принцип податкової служби Нідерландів - орієнтування платників на добровільну сплату податків, а головний напрямок роботи законодавча політика щодо ризиків і керування ними [6]. Тобто основними джерелами виникнення податкових ризиків у системі керування $\epsilon$ моральні, які породжують адміністративні та економічні чинники. У цьому випадку порушено виконання фіскальної функції податків, головною метою якої $\epsilon$ наповнення доходної частини бюджету держави для задоволення потреб суспільства. Має місце ситуація нерівності прав і обов'язків усіх суб'єктів податкових правовідносин та абсолютної свободи держави в їх визначенні.

У процесі аналізу системи керування податковими ризиками доцільно застосовувати системний підхід як основний методологічний інструмент. Податкові ризики характеризують за такими напрямками: об'єкт, джерела виникнення, сукупність досліджуваних інструментів, комплексність дослідження, фінансові наслідки, характер прояву в часі, можливість передбачення.

Найбільший інтерес становлять характеристики податкових ризиків за суб'єктами, які виникають у результаті діяльності фізичних та юридичних осіб і формуються за такими критеріями:

1) кількісні: допустимий ризик, критичний ризик; катастрофічний ризик;

2) якісні: за впливом наслідків ризиків - виправдані, невиправдані; за часом виникнення - перспективні, поточні, оперативні; за функціональними ознаками загальносуспільні, податкові.

Методика якісного аналізу податкових ризиків та їх класифікація недостатньо розроблені. Одну 3 перших класифікацій причин виникнення податкових ризиків запропонувала О.М. Десятнюк: недоліки соціальноекономічного характеру; недоліки організаційно-правового характеру; недоліки нормативно-правового характеру. [7, с. 40] Грунтовніші напрацювання в галузі $\begin{array}{lllll}\text { податкової } & \text { ризикології } & \text { В. В. Вітлінському }\end{array}$ О. М. Тимченко [8, с. 133-136]. У подальшому, класифікацію джерел виникнення податкових ризиків була удосконалила Н. О. Свтушенко [9] (рисунок).

Вищенаведена класифікація за своєю сутністю глибоко обгрунтовує появу податкових ризиків, але, щоб деталізувати джерела їх виникнення, до суб'єктів податкових ризиків як «для держави», так і «для платника» було додано ризики, пов'язані з людським капіталом, та інформаційні ризики.

Невипадково для характеристики податкового ризику поряд із людським капіталом зазначено рівень інформаційного забезпечення. Сьогодні інформація стає найістотнішим чинником функціонування економічної системи. Керівник на будьякому рівні керування стикається 3 проблемами економічного інформаційного забезпечення: недостатністю інформації, появою нових напрямків розвитку інформаційних і технологічних структур, обмеженістю доступу до статистичних і нормативних даних. Тому система керування ризиками повинна включати заходи 3 постійного контролю за фінансово-господарською діяльністю платників податків (здійснення перевірок), моніторингу сплати ними податків, виявлення порушень у сплаті податків та зборів, а також найголовніше - недопущення повторного використання схем ухилення, які були виявлені органами Державної податкової служби раніше. 


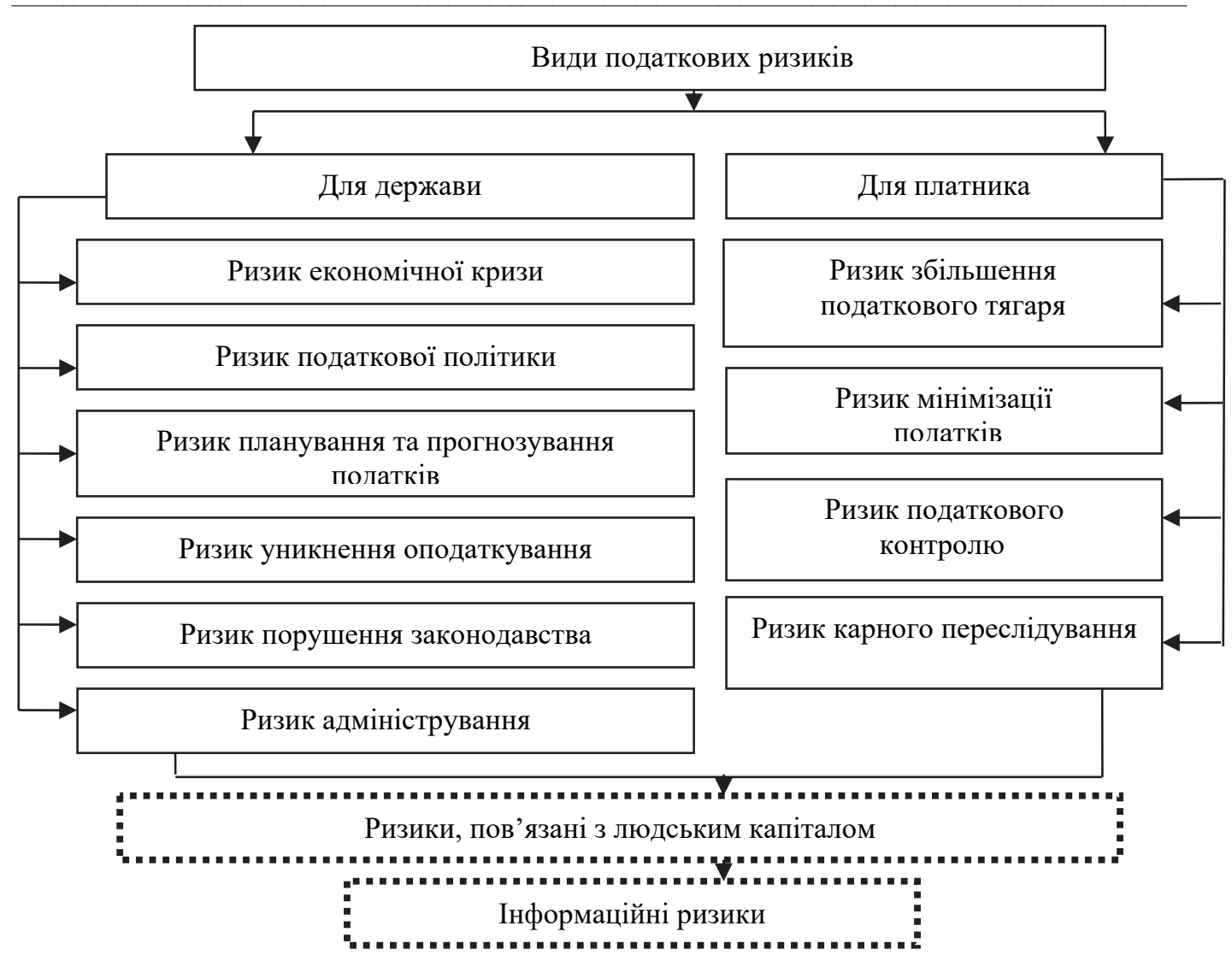

Рисунок. Удосконалена класифікація видів податкових ризиків [ 9, с. 63]

Подальший моніторинг ризикових позицій у системі керування податковим ризиком включає порядок взаємодії підрозділів під час виявлення ризиків i запобігання їм, а також удосконалення методів нейтралізації будь-яких можливих наслідків ризиків. Щоб здійснювати контроль і не допускати повторні ухилення від сплати податків, а також ефективно керувати податковими ризиками, органи державної податкової служби створено єдину базу даних податкових ризиків (БДПР). У цій базі систематизовано недоліки й порушення нормативноправових актів суб'єктами підприємництва в процесі господарської діяльності, загальні ознаки, за якими їх можна виявити, схеми ухилень від оподаткування. Завдяки постійній контрольній роботі, в умовах нестабільного законодавства та виникнення нових видів, форм і методів господарської діяльності БДПР змінюють, доповнюють новими ризиками.

Щоб визначити податкові ризики в системі керування ними, застосовують метод систематизації платників за групами згідно з визначеними стандартами. Така систематизація грунтується на принципах мікрорівневого аналізу підприємств. Один 3 видів такого аналізу - автоматизована перевірка й аналіз податкової звітності платників податків. Такий підхід дозволяє застосовувати на практиці нову стратегію організації контрольно-перевірочної роботи, визначену Департаментом податкового контролю України. Головне завдання служби - це формувати неупереджені відносини 3 платниками податків, за яких податкова служба буде партнером легального бізнесу, знижуючи податковий тиск і створюючи сприятливі 
умови для зростання економіки [10, с.11-12]. На практиці це означає, що головним критерієм відбору підприємств до перевірки $\epsilon$ наявність у їх фінансовогосподарській діяльності ризиків несплати належних платежів до бюджету. Проаналізуємо основні показники контрольно-перевірчої роботи Департаменту податкового та митного аудиту за січень 2014 - грудень 2015 pр. (таблиця).

Основні показники контрольно-перевірчої роботи

Таблиця

Департаменту податкового та митного аудиту за січень-грудень 2014-2015 рр. [11]

\begin{tabular}{|c|c|c|c|c|c|c|}
\hline Показник & \multicolumn{2}{|c|}{ Кількість перевірок, результати яких } \\
& узгджено & \multicolumn{2}{c|}{$\begin{array}{c}\text { Суманарахованих грошових зобов’язань, } \\
\text { яку слід погасити, тис.грн. }\end{array}$} \\
\cline { 2 - 7 } & усього & $\begin{array}{c}\text { у т.ч. } \\
\text { плано- } \\
\text { вих }\end{array}$ & $\begin{array}{c}\text { у т.ч. позапла- } \\
\text { нових }\end{array}$ & усього & $\begin{array}{c}\text { у т.ч. за } \\
\text { плановими } \\
\text { перевірками }\end{array}$ & $\begin{array}{c}\text { у т.ч. за } \\
\text { позаплановими } \\
\text { перевірками }\end{array}$ \\
\hline Усього за 2014 р. & 33613 & 5104 & 28509 & 7963822 & 3521970 & 4441852 \\
\hline Усього за 2015 р. & 21663 & 3609 & 18054 & 4611007 & 1777802 & 2833206 \\
\hline Відхилення & -11950 & -1495 & -10455 & -3352815 & -1744168 & -1608646 \\
\hline
\end{tabular}

Нова стратегія організації контрольно-перевірчої роботи сприятиме істотному зменшенню кількості планових перевірок. Так, до плану-графіка проведення документальних перевірок за січень - грудень 2015 р. включено 21663 суб'єкти господарювання, що на 11950 суб'єктів, менше, ніж у період січеньгрудень 2014 р. Кількість позачергових перевірок у період січень 2014 - грудень 2015 pр. зменшилась на 10445. Крім того, розгорнутий звіт дозволяє чітко розподілити суб'єкти господарювання за рівнем ризику та зосередити увагу на суб'єктів, які мають високу вірогідність несплати податків або приховування об'єктів оподаткування.

Сучасні підходи до організації контрольно-перевірчої роботи дають підстави не застосовувати пост-контроль до сумлінних платників податків, водночас робити його невідворотним для несумлінних. Тобто планові контрольно-перевірчі заходи вживають винятково щодо тих підприємств, які свідомо не сплачують або сплачують не в повному обсязі платежі до бюджету, використовуючи схеми ухилення від оподаткування. Це підтверджено статистичними даними, наприклад, загальна сума донарахованих грошових зобов'язань, яка підлягає погашенню, за січень 2014 - грудень 2015 рр. скоротилася на 3352815 тис. грн.

Висновки. Таким чином, 3'ясовано, що податковий ризик, як і економічний ризик, зазвичай оцінюють як вартісний вимір результатів діяльності людського капіталу в умовах невизначеності та недосконалості інформаційного забезпечення. Щоб мінімізувати й протидіяти податковим ризикам, доцільно розглядати їх як систему керування. Система керування податковими ризиками - це узагальнення результатів контролю та систематизація недоліків і порушень нормативно-правових актів суб'єктами підприємництва у процесі господарської діяльності, схем ухилень від оподаткування, а також загальних ознак, що можуть вказувати на наявність вищенаведених порушень. За таких умов використання системного підходу щодо керування податковими ризиками є елементом підвищення ефективності керування податками. Але на рівень ефективності обов'язково впливатимуть можливості людського капіталу та досконалість інформаційного забезпечення.

Щоб усунути джерела виникнення податкових ризиків, вітчизняна податкова система потребує:

- реформування податкової системи відповідно до обраних теоретичних засад іï побудови; 
- належного виконання принципів, що регулюють відносини у сфері оподаткування;

- підтримання фіскальної спрямованості податкової системи на стале економічне зростання;

- удосконалення організації операційної діяльності податкових департаментів, внутрішнього контролю та процесу збору даних;

- перехід від каральної до стимулювальної функції у сфері оподаткування.

Вищенаведені міркування дозволяють зробити висновок, що податкові ризики слід розглядати як наукову основу для розробки критеріальної бази, побудови систем забезпечення національної безпеки у сфері оподаткування. Системний підхід у теорії і практиці оподаткування дозволить передбачати появу негативних наслідків, значно підвищить ефективність моніторингу ризиків i практичного керування ними та стане основою для подальшого дослідження заходів із мінімізації ризиків податкової системи. Зменшивши рівень податкових злочинів (ухилень від сплати податків), Державна податкова служба збільшить рівень податкових надходжень до бюджету, що, у свою чергу, забезпечить зростання вітчизняної економіки та зменшення ії тіньового сектора.

Науковою новизною дослідження є поглиблення та визначання природи, сутності податкових ризиків, а також обгрунтування концептуальних основ ефективності їх керування шляхом запровадження системного підходу.

Урахування системного підходу дозволить фіскальним службам ефективно керувати податковими ризиками.

Перспективним напрямком досліджень є перегляд нормативної документації Державної фіскальної служби на основі системного підходу й урахування податкового ризику як виміру результатів діяльності людського капіталу й недосконалого інформаційного забезпечення.

\section{Бібліографічні посилання}

1. Свтушенко, Н. О. Механізми мінімізації економічних ризиків на промислових підприємствах [Електронний ресурс]: автореф. дис. ... канд. екон. наук: 08.00.04 - Економіка та управління підприємствами (за видами економічної діяльності) / Свтушенко Н.О. - Маріуполь, 2011. - Режим доступу: http://mydisser.com/en/catalog/view/8760.html. - Заголовок з екрана.

2. Наказ ДПА України «Про затвердження Методичних рекомендацій 3 моніторингу податкових ризиків» від 23.10.2001 р. № 428.

3. Пинская, М. Р. Налоговый риск: сущность и проявление [Электронный ресурс] / М. Р. Пинская. - Режим доступа: http://organictheory.ru/taxplaning/taxrisk/. - Загл. с экрана.

4. Десятнюк, О. М. Управління податковими ризиками - нова парадигма розбудови податкової системи України [Текст] / О. М. Десятнюк // Вісн. нац. ун-ту «Львів. Політехніка». Серія: Менеджмент та підприємництво в Україні: етапи становлення і проблеми розвитку. - 2007. - № 606. - С. 355-362.

5. Zech, J. Risk Management als System. Zeitschrift fur die gesamte [Text] / J. Zech // Versicherungswissenschaft (Zfgvw). - 1983. - H. 4. - S. 646-647.

6. Хенк, Д. Податкова та митна адміністрації Нідерландів. Стратегія розвитку [Електронний ресурс] / Д. Хенк. - Режим доступу: www.sta.gov.ua. - Заголовок з екрана.

7. Десятнюк, О. М. Моніторинг податкових ризиків (навч.-метод. посіб. слухачів Центру підготовки магістрів) [Текст] / О. М. Десятнюк. - Тернопіль: Воля, 2003. $-168 \mathrm{c}$. 
8. Вітлінський, В. В. Джерела і види податкових ризиків, їх взаємозв'язок [Текст] / В. В. Вітлінський, О.М.Тимченко // Фінанси України. - 2007. - № 3. C. $132-139$

9. Свтушенко, Н. О. Механізми мінімізації економічних ризиків на промислових підприємствах [Електронний ресурс]: дис. ... канд. екон. наук: спеціальність 08.00.04 - Економіка та управління підприємствами (за видами економічної діяльності) / Євтушенко Н. О. - Х.: ХНАДУ, 2011. - 187 с.

10. Крухмальов, С. У поточному році передбачається охопити плановими перевірками лише підприємства з високими показниками ризиків несплати податків / С. Крухмальов // Вісник податкової служби України. - 2012. - № 12. - С. 11-12.

11. Державна фіскальна служба України [Електронний ресурс]: звіт про виконання Плану основних питань економічної та контрольної роботи Державної податкової адміністрації України на 2014 та 2015 pp. - Режим доступу: www.stat.gov.ua. - Заголовок з екрана.

12. Паскар, I. О. Податкові ризики та система управління ними [Електронний ресурс] / I. О. Паскар, О. І. Савчук, Т. М. Сачук. - Режим доступу: http://intkonf.org/paskar-i-o-savchuk-o-i-savchuk-t-m-podatkovi-riziki-ta-sistemaupravlinnya-nimi/. - Заголовок з екрана.

\section{Bibliographic references}

1. Yevtushenko, N. O. Mekhanizmy minimizatsii ekonomichnykh ryzykiv na promyslovykh pidpryiemstvakh [Electronic resource]: avtoref. dys. ... kand. ekon. nauk: 08.00.04 - Ekonomika ta upravlinnia pidpryiemstvamy (za vydamy ekonomichnoi diialnosti) / Yevtushenko N. O. - Mariupol, 2011. Access mode: http://mydisser.com/en/catalog/view/8760.html.

2. Nakaz DPA Ukrainy «Pro zatverdzhennia Metodychnykh rekomendatsii z monitorynhu podatkovykh ryzykiv» vid 23.10.2001 r. № 428.

3. Pynskaia, M. R. Nalohovyi rysk: sushchnost y proiavlenye [Electronic resource] / M. R. Pynskaia. - Rezhym dostupa: http://organictheory.ru/taxplaning/taxrisk/. - Zahl. s эkrana.

4. Desiatniuk, O. M. Upravlinnia podatkovymy ryzykamy - nova paradyhma rozbudovy podatkovoi systemy Ukrainy / O. M. Desiatniuk // Visn. nats. un-tu «Lviv. Politekhnika». Seriia: Menedzhment ta pidpryiemnytstvo v Ukraini: etapy stanovlennia i problemy rozvytku. - 2007. - № 606. - S. 355-362.

5. Zech, J. Risk Management als System. Zeitschrift fur die gesamte [Text] / J. Zech // Versicherungswissenschaft (Zfgvw). - 1983. - H. 4. - S. 646-647.

6. Khenk, D. Podatkova ta mytna administratsii Niderlandiv. Stratehiia rozvytku [Electronic resource] / D. Khenk. - Access mode: www.sta.gov.ua.

7. Desiatniuk, O. M. Monitorynh podatkovykh ryzykiv (navch.-metod. posib. slukhachiv Tsentru pidhotovky mahistriv) / O. M. Desiatniuk. - Ternopil: Volia, 2003. $-168 \mathrm{~s}$.

8. Vitlinskyi, V. V. Dzherela i vydy podatkovykh ryzykiv, yikh vzaiemozv'iazok / V. V. Vitlinskyi, O. M. Tymchenko // Finansy Ukrainy. - 2007. - № 3. - S. 132-139

9. Yevtushenko, N. O. Mekhanizmy minimizatsii ekonomichnykh ryzykiv na promyslovykh pidpryiemstvakh [Electronic resource]: dys. ... kand. ekon. nauk: spetsialnist 08.00.04 - Ekonomika ta upravlinnia pidpryiemstvamy (za vydamy ekonomichnoi diialnosti) / Yevtushenko N. O. - Kh.: KhNADU, 2011. $-187 \mathrm{~s}$.

10. Krukhmalov, S. U potochnomu rotsi peredbachaietsia okhopyty planovymy perevirkamy lyshe pidpryiemstva z vysokymy pokaznykamy ryzykiv nesplaty podatkiv / C. Krukhmalov // Visnyk podatkovoi sluzhby Ukrainy. -2012 . - № 12. - S. 11-12.

11. Derzhavna fiskalna sluzhba Ukrainy [Electronic resource]: zvit pro vykonannia Planu osnovnykh pytan ekonomichnoi ta kontrolnoi roboty Derzhavnoi podatkovoi administratsii Ukrainy na 2014 ta 2015 rr. Access mode: www.stat.gov.ua.

12. Paskar, I. O. Podatkovi ryzyky ta systema upravlinnia nymy [Electronic resource] / I. O. Paskar, O. I. Savchuk, T. M. Sachuk. - Access mode: http://intkonf.org/paskar-i-o-savchuk-o-i-savchuk-t-mpodatkovi-riziki-ta-sistema-upravlinnya-nimi/.

Надійшла до редколегії 11.03.2016 